EWA M. KWIATKOWSKA ${ }^{1}$, ARKADIUSZ TRELA ${ }^{2}$

\title{
The Institution of Succession Management - a New Opening for a Natural Person's Enterprise?
}

\begin{abstract}
A sole proprietorship is the most common form of running a business. The number of enterprises operated in Poland has been growing dynamically for over 30 years. At the same time, the population of Poland is the fastest ageing society in the EU. In the light of the above, many enterprises may soon face the problem of maintaining business continuity in the event of death of their owners. The article attempts to evaluate the implementation of the institution of succession management of a natural person's enterprise into the Polish legal framework one year after new solutions were offered to Polish entrepreneurs. To this end, the way how entrepreneurs make use of this institution has been analysed.
\end{abstract}

Keywords: succession management, sole proprietorship, CEIDG, society ageing, business continuity

$1 \quad$ Ewa M. Kwiatkowska, PhD - Kozminski University; e-mail: ewcia@kozminski.edu.pl; ORCID: 0000-0001-7576-1996.

$2 \quad$ Arkadiusz Trela - ATR Consulting; e-mail: arkadiusz@trela.at; ORCID: 0000-0002-5282-7849. 


\section{Introduction}

A significant challenge to be faced not only by Poland but also by most European countries is the ageing of societies. In 2018, the population of Poland was 38.4 million, with over 6.7 million aged $65+$, and almost 1.7 million aged $80+$. Senior citizens (people aged $65+$ ) made about $17.5 \%$ of the population, and people aged $80+$ made $4.3 \%$ of the population. Since 2000 , there has been a $42 \%$ increase in the population of the elderly (in 2000 , the $65+$ age group made $12.4 \%$ of the entire population). ${ }^{3}$ According to predictions, Poland's population is to be composed of $33 \%$ of people aged $65+$ and $16 \%$ aged $80+$ by $2070 .{ }^{4}$ Moreover, the population of Poland is the fastest ageing society from among all EU countries. According to Statistics Poland's predictions, the number of people aged $60+$ will be close to 10 million $(1 / 4$ of the country's population) by 2020, and in 2030 it will exceed 10.7 million (30\% of the population). It is also said that there will be over 2.2 million of people aged $80+$ in $2030 .{ }^{5}$ The trend affects virtually all spheres of our life. It is observed among entrepreneurs as well.

Maintaining continuity is essential to any activity, including business activity. In general, an entrepreneur starting and running a business assumes that it is going to be lasting. But there may occur many difficulties, including those resulting from a business owner's death. This can have a particularly severe impact on sole proprietorships. In the case of companies, a partner's death may also result in a temporary or permanent inability to make the necessary decisions. A successful process of succession, in turn, may not only determine the survival but also the development of a family business to be run by the generations to come. ${ }^{6}$

3 Statistics Poland, Ludność. Stan i struktura oraz ruch naturalny w przekroju terytorialnym w 2018 r. Stan $w$ dniu 31.XII [Population. Size and structure and vital statistics in Poland by territorial division in 2018. As of December, 31], Warszawa 2019, pp. 16-18; Ibidem, Excel tablica 1. Ludność według ptci i wieku $w 2018$ r. Stan w dniu 31.XII. [Excel table1. Population by sex and age in 2018. As of December 31].

4 European Commission, Directorate-General for Economic and Financial Affairs, The 2018 Ageing Report. Economic \& Budgetary Projections for the 28 EU Member States (2016-2070), Luxembourg 2018, p. 23.

5 Council of Ministers, Strategia na rzecz Odpowiedzialnego Rozwoju do roku 2020 (z perspektywa do 2030 r.), Warszawa 2017, p. 149.

$6 \quad$ K. Wojarska-Aleksiejuk, P. Aleksiejuk, Ustawa o zarzadzie sukcesyjnym w kontekście sukcesji firm rodzinnych w Polsce, "Nowy Przegląd Notarialny" 2019, 1(77), p. 43. 
The act on the succession management of a natural person's enterprise, passed on 5 July 2018, entered into force on 25 November 2018. ${ }^{7}$ Since that day, sole proprietors have had the opportunity to appoint a succession manager for their business. The instrument makes it possible for them to decide on the future fate of the business they run in the event of their death. The legislator arranged for a simple and free form of establishing a succession manager, which involves e.g. making a relevant entry online in the Central Registration and Information on Business (CEIDG) ${ }^{8}$ database. The article presents an analysis of the utilisation of the institution of succession management as of one year after the adoption of new legal regulations, which makes it possible to attempt to evaluate the effects of its implementation.

\section{Entrepreneurship in the Polish economic reality}

After the period of socialist economy there occurred a dynamic increase in the number of enterprises in Poland thanks to the so-called Wilczek act, which was a completely new set of regulations defined in the act of 23 December1988 on business activity. ${ }^{9}$ According to the act, which came into force on 1 January 1989, "everything which is not forbidden by law is permitted." Article 1 stipulated that everyone was allowed to start and run a business activity on equal terms subject to the provisions defined by the law, and Art. 4 stipulated that business entities could undertake any activities and actions which were not forbidden by the law as part of the business they ran. Back then, the act was an unusual legal solution. It was enacted by communist authorities, after all. It was one of the most liberal free-market acts in the world at the time, and triggered a dynamic development of entrepreneurship from the first day of its enactment. It remained effective until 1 January 2001. By that time, it had been amended 62 times, and the number of business activity areas that were subject to a concession had grown from 11 to $202 .{ }^{10}$

In 2016, enterprises generated a gross value added in the amount of PLN 1.366 billion zloty, which was as much as $73.6 \%$ of the share in the production of

7 In Polish: Ustawa z dnia 5 lipca 2018 r. o zarządzie sukcesyjnym przedsiębiorstwem osoby fizycznej, Act of 5 July 2018 on the succession management of a natural person's enterprise (Journal of Laws of 2018, item 1629 as amended).

8 Poland's database and register of entrepreneurs; in Polish: Centralna Ewidencja i Informacja o Dziatalności Gospodarczej.

9 In Polish: Ustawa z dnia 23 grudnia 1988 r. o działalności gospodarczej, Act of 23 December 1988 on business activity (Journal of Laws No. 41, item 324).

10 T. Grabarczyk, Zapomniana ustawa, czyli jak Mieczysław Wilczek zreformowat Polske, http://www.civisliber. org/zapomniana-ustawa-czyli-jak-mieczyslaw-wilczek-zreformowal-polske/ (access: 10.11.2019). 
GDP. ${ }^{11}$ Micro, small, and medium enterprises play particularly important role in economy, and their number is consistently growing. The business sector is dominated by microenterprises. They make as much as $96.5 \%$ of all enterprises in Poland. Their share in the GDP produced in 2016 was over 30\%. This translates into 40\% of the GDP generated by enterprises overall. What is important from the point of view of succession is that $72.6 \%$ microenterprises have been operating for 5 years or longer. ${ }^{12}$ The growing significance of the SME sector in the national economy should be looked at from the long-term perspective, though. The share of this sector in generating GDP increased from about 30\% in mid-1990s to almost 50\% in 2016. ${ }^{13}$ Enterprises not only produce almost $3 / 4$ of Poland's GDP but also play an important part in the labour market. The number of people working at various enterprises is consistently growing. At the end of 2017, it was almost 9.9 million people, which was almost $60 \%$ of Poland's entire working population of 16.5 million. The employment market is dominated by large enterprises with a share of $42.5 \%$ in 2017. In the case of smaller enterprises, the data for the share in the employment market was as follows: $22 \%$ for medium enterprises, $20.5 \%$ for microenterprises, and $15 \%$ for small enterprises. ${ }^{14}$

According to the data found in the REGON ${ }^{15}$ register, the most popular form of conducting business activity in Poland is a sole proprietorship operated by a natural person. At the end of 2016, there were almost 3 million natural persons running a business and nearly 300 thousand civil law partnerships in the register. At the same time, there were just a bit over 500 thousand commercial companies there. What is more, in 2016 , over $80 \%$ of those starting their business activity opted for a sole proprietorship. ${ }^{16}$ In 2018, according to the Ministry of Entrepreneurship and Technology's data, family-owned businesses were about $36 \%$ of all enterprises in Poland, generating $10 \%$ of GDP and employing half of all employees. ${ }^{17}$ According

11 Polish Agency for Enterprise Development, Raport o stanie sektora małych i średnich przedsiębiorstw $w$ Polsce, Warszawa 2019, p. 5.

12 Ibidem, p. 10.

13 Ibidem, p. 5; Polish Foundation for Small and Medium Enterprise Promotion and Development, Stan sektora małych iśrednich przedsiębiorstw w Polsce. Raport za lata 1995-1996, Warszawa 1997, p. 13.

14 Polish Agency for Enterprise Development, Raport..., p. 6.

15 REGON (National Official Business Register) is a Polish register of business entities, and a REGON number is a statistical identification number.

16 In Polish: Uzasadnienie do rządowego projektu ustawy o zarządzie sukcesyjnym przedsiębiorstwem osoby fizycznej z projektami aktów wykonawczych. Explanatory statement to the government's draft resolution on the succession management of a natural person's enterprise with draft secondary legislation, Sejm paper no. 2293, Sejm of the $8^{\text {th }}$ term, p. 3 .

17 Ministry of Entrepreneurship and Technology, Sukcesja firm jednoosobowych. Ustawa o zarzadzie sukcesyjnym przedsiębiorstwem osoby fizycznej. Praktyczny poradnik, Warszawa 2018, p. 9. 
to the Supreme Audit Office, the total number of CEIDG entries of natural persons running a business activity (including partners in civil law partnerships) grew by $3.2 \%$, i.e. from 2.609 million to 2.694 million, within two years (2015-2017). At the same time, according to the statistics provided by Poland's Social Insurance Institution (In Polish: Zakład Ubezpieczeń Społecznych - ZUS), the number of entrepreneurs (subject to the obligation of entry in CEIDG) deregistered from insurance on account of death grew in the same period as follows: 3.2 thousand in 2015, 3.3 thousand in 2016, and 3.9 thousand in 2017. The situation led to the loss of employment for 6.8 thousand people in 2015, 7 thousand people in 2016, and 8.3 thousand people in $2017 .{ }^{18} 750$ entrepreneurs were deregistered on an average monthly basis throughout 2017 because of death. ${ }^{19}$ The data proves that it is reasonable to initiate legislative measures and regulate the matters connected with succession management of enterprises of natural persons running their business on the basis of a CEIDG entry.

The question of maintaining business continuity should also be considered from the point of view of different stakeholder groups. It is obvious that succession should be considered as a tool designed to maintain business activity from the perspective of an entrepreneur. Of an entrepreneur's heirs, to be more specific. But we should not ignore the significance of succession as viewed from the point of view of the labour market and national economy. The problem of business discontinuity may be especially problematic in the segment of microenterprises. However, it is important to bear in mind that on the basis of a CEIDG entry, natural persons are allowed to run a business not only on a micro scale; their business may actually generate millions of zloty in turnover. ${ }^{20}$

Until the day of adoption of the institution of succession management in the Polish legal framework, the death of a sole proprietor meant the end of their business activity, considered inseparable from them as the owner of the business in question. ${ }^{21}$ Therefore, the failure to consider the need to maintain the continuity of a business of a deceased sole proprietor was a problem many entities had been

18 Supreme Audit Office, Informacja o wynikach kontroli: Działania organów państwa wobec problematyki dziedziczenia przedsiębiorstw, Warszawa 2018, pp. 19-20.

19 Ibidem, p. 25.

20 Ibidem, p. 10; Polish Agency for Enterprise Development, Weszła w życie ustawa o sukcesji - łatwiejsza zmiana pokoleniowa, 23.11.2018, https:/www.parp.gov.pl/component/content/article/50377:wchodziw-zycie-ustawa-osukcesji-latwiejsza-zmiana-pokoleniowa-w-firmach (access: 10.08.2019).

21 In Polish: Ocena skutków regulacji do rządowego projektu ustawy o zarządzie sukcesyjnym przedsiębiorstwem osoby fizycznej z projektami ustaw aktów wykonawczych. Regulatory impact assessment for the government's draft resolution on the succession management of a natural person's enterprise with draft secondary legislation, Sejm paper no. 2293 , Sejm of the $8^{\text {th }}$ term, p. 1. 
facing for many years. In many cases, the uncertainty concerning the turnover, caused by prolonged inheritance proceedings, led to a sort of suspension period. The existence of many business entities could be at risk. ${ }^{22}$ This also posed a threat to jobs. Death of an entrepreneur meant, among others: expiry of the tax ID (NIP) number, problems with tax settlements, difficulties with accessing bank accounts, expiry of various administrative decisions such as concessions, licenses, and permits, and expiry of contracts - like employment contracts. ${ }^{23}$ There was no way to even temporarily use such a deceased entrepreneur's company name identifying the entrepreneur and the business they ran in legal transactions. Legal successors could resume the activity only once all the relevant inheritance issues were settled, when a new business was registered, when they employed the necessary human resources, and obtained appropriate permits from public administration authorities. The continuation of a deceased sole proprietorship's business activity, which actually involved starting a business anew, had to be therefore postponed. ${ }^{24}$ In the light of the above, it is puzzling that the issue of maintaining business continuity after an entrepreneur's death had been passed over in legal regulations until the time of enactment of the act on the succession management of a natural person's enterprise, passed on 5 July 2018. When presenting the draft version of the act, its initiator stressed it aimed at reducing the number of cases where the death of an owner of an enterprise run by a natural person or of a partner in a civil law partnership caused sudden and disorganised discontinuation of business activity and complications in economy. ${ }^{25}$ The adopted solutions are to make it possible to continue business activity until all the relevant inheritance issues are settled. ${ }^{26}$

\section{Succession management in the Polish legal framework}

Article 1 of the act on the succession management of a natural person's enterprise "regulates the principles of temporary management of an enterprise after the death of the owner who conducted a business activity in their own name on the basis of an entry in the Central Registration and Information on Business database (here-

22 J. Bieluk, Ustawa o zarządzie sukcesyjnym przedsiębiorstwem osoby fizycznej. Komentarz, Warszawa 2019, p. 2.

23 Ministry of Entrepreneurship and Technology, Sukcesja firm jednoosobowych. Ustawa o zarzadzie sukcesyjnym przedsiębiorstwem osoby fizycznej. Prezentacja, Warszawa 2019, https://www.gov.pl/web/ rozwoj/sukcesja (access: 28.10.2019).

24 Supreme Audit Office, op. cit., pp. 5 and 10.

25 Explanatory statement to the government's draft resolution on succession management..., p. 146.

26 Supreme Audit Office, op. cit., p. 5. 
inafter referred to as "CEIDG") and of continuation of a business activity pursued with the use of the enterprise in question. ${ }^{\prime 27}$ In the explanatory statement to the government's draft resolution on the amendment of some acts in order to reduce the regulatory burden, the initiator of the draft stressed that the act "addressed the most important and most urgent problem regarding succession in business in connection with the death of an entrepreneur registered in CEIDG." ${ }^{28}$ The legislator limited the applicability of the solutions at issue to the entities registered in the CEIDG database. The measure is to ensure the security of economic trading by highlighting the existence of a person acting as a succession manager in a given enterprise. ${ }^{29}$ The act makes it possible for an entrepreneur conducting a business activity in their own name to establish a succession manager in the event of the entrepreneur's death by appointing the person to act as such a succession manager or by stipulating that a given proxy will become such a succession manager with the entrepreneur's death (Art. 9 section 1). Pursuant to Art. 9 section 2, appointing a succession manager and the appointee's consent to act as such a succession manager shall be null and void unless made in writing. Next, pursuant to Art. 10, the entrepreneur will be required to submit a request to have the appointed succession manager entered in the CEIDG database. It is an alternative solution to succession plans, where the successor would take over the management of an enterprise when the enterprise's current owner was still alive. ${ }^{30}$ The implemented legal solution cannot be overestimated from the point of view of business continuity. The virtually automatic substitution of a deceased entrepreneur for a succession manager makes it possible for a business entity to keep functioning in an uninterrupted way. Thanks to the implementation of this institution, the operations of an enterprise of a deceased entrepreneur are not suspended. The enterprise retains its tax identification number, the contracts concluded with its employees do not expire, nor do

27 Art. 1 of the act of 5 July 2018 on the succession management of a natural person's enterprise (Journal of Laws of 2018, item 1629). The name of the quoted act, pursuant to Art. 66 item 1 of the act of 31 July 2019 on the amendment of some acts in order to reduce the regulatory burden (Journal of Laws of 2019, item 1495) will change its Polish name (now: ustawa o zarządzie sukcesyjnym przedsiębiorstwem osoby fizycznej) on 1 January 2020 to: ustawa o zarządzie sukcesyjnym przedsiębiorstwem osoby fizycznej $i$ innych ułatwieniach zwiazanych $z$ sukcesja przedsiębiorstw (the act on the succession management of a natural person's enterprise and other facilities connected with business succession), and Art. 1, according to Art. 66 item 3 of the said amendment, will become Art. 1 item 1.

28 In Polish: Uzasadnienie do rządowego projektu ustawy o zmianie niektórych ustaw w celu ograniczenia obciązen regulacyjnych. Explanatory statement to the government's draft on the amendment of some acts in order to reduce the regulatory burden, Sejm paper no. 3622, Sejm of the $8^{\text {th }}$ term, p. 2.

29 Explanatory statement to the government's draft resolution on succession management..., p. 12.

30 Ibidem, p. 18. 
other agreements, concessions, licenses or permits. ${ }^{31}$ The protection of the rights of stakeholders involved in the functioning of the enterprise - including heirs, employees, consumers or business partners - is reinforced. ${ }^{32}$ It is possible to maintain the existing business renown and protect the interests of entities dependent on the existence of the enterprise. ${ }^{33}$

In the event where an entrepreneur, alive, has appointed a succession manager, the appointee has agreed to perform this function, and an appropriate entry has been made in the CEIDG database, pursuant to Art. 6 section 1, when this entrepreneur dies, a succession manager is established, pursuant to Art. 7 section 1 item 1 . Only one person may act as a succession manager at a time (Art. 11 section 1). But an entrepreneur appointing a succession manager in case of the entrepreneur's death may also, pursuant to Art. 11 section 2, appoint a so-called substitute successor, who will manage the enterprise if the originally appointed succession manager appears to be unable to do it.

There is an option to establish a succession manager even in a situation where an entrepreneur has not made use of the solution provided for in Art. 9 and has not appointed a succession manager during their lifetime or has not fulfilled their obligation under Art. 10, i.e. has not submitted a relevant request for an entry to be made in CEIDG. In such circumstances, in order for the appointment of a succession manager to be effective, it needs to take the form of a notarial deed. The duly authorised persons, enumerated in Art. 12 sections 1 and 2, have two months from the date of the entrepreneur's death to appoint a succession manager (Art. 12 section 10). The deadline given for this two-month period may not be reinstated. ${ }^{34}$

In the event where succession management has been established following of an entrepreneur's death, there needs to be an annotation reading "in inheritance" (in Polish: $w$ spadku) made to the CEIDG entry, pursuant to Art. 5 section 1 item 2a of the act on Central Registration and Information on Business Activity and on Information Points for Businesses. ${ }^{35}$ Pursuant to Art. 17 section 1 of the act on succession

31 Ministry of Entrepreneurship and Technology, Sukcesja firm jednoosobowych. Ustawa o zarządzie sukcesyjnym przedsiębiorstwem osoby fizycznej. Prezentacja...

32 Explanatory statement to the government's draft resolution on succession management..., p. 8.

33 K. Kopaczyńska-Pieczniak, Status prawny zarządcy sukcesyjnego, "Przegląd Prawa Handlowego" 2018, 12, p. 6.

34 P. Blajer, Zarząd sukcesyjny przedsiębiorstwem osoby fizycznej. Pytania i odpowiedzi. Wzory pism. Przepisy, Warszawa 2019, pp. 62-63.

35 In Polish: Ustawa z dnia 6 marca 2018 r. o Centralnej Ewidencji i Informacji o Działalności Gospodarczej i Punkcie Informacji dla Przedsiębiorcy. Act of 6 March 2018 on Central Registration and Information on Business Activity and on Information Points for Businesses (uniform text in the Journal of Laws of 2019, item 1291 as amended). 
management, "in matters connected with running an enterprise in inheritance, the succession manager shall use the current business name of the deceased entrepreneur with the annotation reading 'in inheritance' ( $w$ spadku) appended thereto." Such an annotation will make it clear for an enterprise's business partners and other stakeholders that its owner has passed away and their business is run by a succession manager.

According to Art. 2 section 1 of the act on succession management, "an enterprise in inheritance includes both intangible and tangible assets used by the entrepreneur to conduct their business activity and being their property at the moment of their death." Section 4 of the quoted provision stipulates that "(...) the provisions of the act regarding enterprises in inheritance are applied accordingly to an entrepreneur's share in the assets of all partners in a civil law partnership." The statutory solutions are therefore tools that may offer natural persons' enterprises and civil law partnerships a way to continue their functioning uninterruptedly in the event of their owner's (entrepreneur's) death. The notion of an enterprise in inheritance denotes the period from an entrepreneur's death until the expiry of: succession management (if it has been established) or the entitlement to appoint a succession management (in the event it has not been appointed). ${ }^{36}$

A succession manager's obligation is to run a deceased entrepreneur's enterprise, meaning an enterprise in inheritance (Art. 18). But such a manager does not pursue business activity within the meaning of the provisions of the Entrepreneurs' Law since they do not act on their own account, ${ }^{37}$ and only substitute the actual owner, meaning that they act for the heirs to an enterprise in inheritance. Pursuant to Art. 21 section 1, "a succession manager acts in their own name, on the account of the owner of an enterprise in inheritance." Such a manager performs ordinary management activities (Art. 22 section 1). Their actions result in changes in the assets of the enterprise in inheritance they manage. ${ }^{38}$

The institution of succession management is an interim solution. Succession management expires after 2 years of its establishment (Art. 59 section 1 item 7), and a court, for legitimate reasons, may extend this period by no more than 5 years of the date of the entrepreneur's death (Art. 60 section 1). The act does not provide for any instruments making it possible to hand over an enterprise to its legal successors

\footnotetext{
36 J. Bieluk, op. cit., p. 12

37 Pursuant to Art. 3 of the act of 6 March 2018 - Entrepreneurs' Law (in Polish: ustawa $z$ dnia 6 marca 2018 r. Prawo przedsiębiorców) (uniform text in the Journal of Laws of 2019, item 1292 as amended), "Business activity is an organised gainful activity performed in one's own name and on a continued basis."

38 M. Sieradzka, Zarząd sukcesyjny przedsiębiorstwem osoby fizycznej - analiza i ocena nowych rozwiązań prawnych (cz. I), "Monitor Prawniczy" 2018, 22, p. 1199.
} 
on a lasting, permanent basis. Even when the institution in question is applied, it will be eventually necessary for the heirs to an enterprise to start a business activity conducted on their own account.

\section{Succession management in practice}

There are over 2.379 million active entrepreneurs in the CEIDG database. ${ }^{39}$ Each one of them may be affected by the need for business succession in the event of a sole proprietor's death. This is most likely, obviously, in the case of those in the most advanced years. According to data from CEIDG, over 220 thousand active entrepreneurs are 65 or older (which makes over $9 \%$ of all active entries in the register), and over 414 thousand of them are at least 60 years old (which is over $17 \%$ of all active entries). ${ }^{40}$ The age distribution of active entrepreneurs has been presented in table 1 .

Table 1. Age of active entrepreneurs

\begin{tabular}{cc}
\hline entrepreneurs' age & percentage of active entrepreneurs \\
\hline $18-24$ & 2.4 \\
$25-34$ & 19.9 \\
$35-44$ & 29.3 \\
$45-54$ & 22.2 \\
$55-64$ & 16.9 \\
$65+$ & 9.3 \\
\hline
\end{tabular}

Source: authors' own work based on data from CEIDG (status as of 7.11.2019).

In over 9 months of the act on succession management being in force, i.e. from 25 November 2018 until the end of August 2019, more than 7 thousand entities were deregistered from the database because of death. ${ }^{41}$ This means that about 785 entrepreneurs per month on average are deregistered for this reason. Over $61 \%$ of them are people aged $60+$. The age distribution among entrepreneurs deregistered from the CEIDG database because of death shown in table 2 proves that almost $45 \%$ of those entrepreneurs were in the $65+$ age group. The second most

\footnotetext{
39 Unpublished data from the CEIDG database (status as of 7.11.2019).

40 Ibidem.

41 Unpublished data from the CEIDG database (data for the period of December 2018-August 2019).
} 
numerous group were people aged 55-64 (27.5\%). The data supports a quite evident conclusion - the older an entrepreneur is, the higher the probability of their death. At the same time, this data also shows that it is urgent to provide for a mechanism of succession, especially in the case of business entities strictly connected with their owners as persons.

Table 2. Percentage of entrepreneurs deregistered from CEIDG as a result of death

\begin{tabular}{cc}
\hline entrepreneurs' age & $\begin{array}{c}\text { percentage of entrepreneurs deregistered } \\
\text { as a result of death }\end{array}$ \\
\hline $18-24$ & 0.6 \\
$25-34$ & 3.5 \\
$35-44$ & 8.6 \\
$45-54$ & 15.0 \\
$55-64$ & 27.5 \\
$65+$ & 44.7 \\
\hline
\end{tabular}

Source: authors' own work based on data from CEIDG (status as of 7.11.2019).

Within nearly one year of the act on succession management being effective (25 November 2018 to 6 November 2019), only 10,864 entrepreneurs appointed, pursuant to Art. 9 section 1 of the act, a succession manager in case of their death. ${ }^{42}$ This means that less than half percent $(0.46 \%)$ of entrepreneurs used the statutory solution implemented almost one year ago. It appears that the measure enabling entrepreneurs to maintain business continuity in the event of their death as provided for by the legislator has not become very popular among businesspeople. Unsurprisingly, the percentage of entrepreneurs who appointed a succession manager in the discussed period grows proportionally to the age of entrepreneurs. However, even in the $65+$ age group only $1.11 \%$ of entrepreneurs appointed a succession manager (Table 3).

Among elderly persons, i.e. in the $80+$ age group, the percentage of those who made use of the solution at issue was the same as among all seniors (1.11\%). Importantly enough, among the youngest entrepreneurs, aged 18-24, only 40 decided to appoint a succession manager. In addition to that, 918 substitute successors were registered in the CEIDG database. ${ }^{43}$ Just under $8.5 \%$ of entrepreneurs who appointed

\footnotetext{
42 Unpublished data from the CEIDG database (status as of 7.11.2019).

43 Ibidem.
} 
a succession manager appointed also, pursuant to Art. 11 section 2, a so-called substitute successor.

Table 3. Age distribution among entrepreneurs who appointed succession managers

\begin{tabular}{ccc}
\hline entrepreneurs' age & $\begin{array}{c}\text { percentage of entrepreneurs who } \\
\text { appointed a succession manager }\end{array}$ & $\begin{array}{c}\text { number of entrepreneurs who } \\
\text { appointed a succession manager }\end{array}$ \\
\hline $18-24$ & 0.07 & 40 \\
$25-34$ & 0.15 & 688 \\
$35-44$ & 0.31 & 2,170 \\
$45-54$ & 0.47 & 2,472 \\
$55-64$ & 0.76 & 3,041 \\
$65+$ & 1.11 & 2,453 \\
\hline
\end{tabular}

Source: authors' own work based on data from CEIDG (status as of 7.11.2019).

7,207 entrepreneurs died in the period from the date the act entered into force until the end of August 2019. A succession manager was established only in $8.7 \%$ of cases. Only in 151 cases (24.1\% of cases of establishment of a succession manager), succession managers were appointed, pursuant to Art. 9 section 1, by entrepreneurs while the latter were still alive. Such a practice of appointing a succession manager means that when an entrepreneur dies, a succession manager is established automatically. Despite the fact that new legal solutions were adopted, the vast majority of succession managers (75.9\%) was appointed, pursuant to Art. 12, already after the entrepreneurs originally managing their enterprises passed away, by duly authorised persons, listed in Art. 12 sections 1 and 2, and then, pursuant to Art. 7 section 1 item 2, established when a notary public made the relevant entry in the CEIDG register. In $13.9 \%$ of cases, succession managers were established within the first 7 days after the entrepreneur's death, and in $70.8 \%$ of cases - within 30 days of the entrepreneur's death. In the remaining cases, succession management was established within the period of 2 months as provided for in Art. 12 section 10. The situation may suggest that heirs to enterprises might see the benefits of making use of the solution discussed in the article. Yet, from the point of view of business continuity, this method of establishing succession managers is far less desired. There exists a certain time gap - a period when there may occur a discontinuity in the activity of a natural person's enterprise as a result of this person's death. 


\section{Conclusion}

A common application of the legal solutions generally available in the domain of succession management may ensure business continuity and reduce the risk of loss of managerial control over an enterprise in the event of its owner's death. According to the regulatory impact assessment provided together with the draft resolution on succession management, the institution of succession management was to reduce the number of cases where the death of an entrepreneur owning an enterprise run by a natural person or being a partner in a civil law partnership causes sudden and disorganised discontinuation of business activity. This should translate into less complications in business trading, which may result from entrepreneurs' deaths. The initiator of the solution argued that entrepreneurs were very much interested in the matter of succession. ${ }^{44}$ A questionnaire survey conducted in $2016{ }^{45}$ proved that $94 \%$ of the surveyed entrepreneurs were aware of the problem of succession. Over $68 \%$ of respondents pointed to an option of running an enterprise after its original owner's death in an unchanged form, operating as the same business (under the same name), using the same statistical (REGON) and tax (NIP) identification numbers, as the best solution in the context of succession. ${ }^{46}$ However, the obtained findings are not reflected in the observed reality. Before the act entered into force, information about the solution at issue was published e.g. on PAED's (Polish Agency for Enterprise Development) website. It encouraged entrepreneurs to appoint succession managers. Moreover, the Ministry of Entrepreneurship and Technology provided a guide regarding the matter and sent information to entrepreneurs and their proxies by email. ${ }^{47}$ Despite the information campaigns organised within one year of the adoption of the institution of succession management, entrepreneurs appeared to be far from keen on utilising the solution in practice. The outreach campaign drew little response from entrepreneurs. Less than $0.5 \%$ of them appointed a succession manager during their lifetime. What is more, only $8.5 \%$ of them appointed a substitute successor. The quoted numbers prove that there is a low level of interest in the institution in question or little knowledge and awareness of the ability to make use of the available legal solution. They may also mean that entrepreneurs have a false impression that the procedure is difficult to

\footnotetext{
44 Regulatory impact assessment..., p. 10.

45 "Nowe rozwiązania prawne dla firm" questionnaire-based survey conducted by the Polish Agency for Enterprise Development for the Ministry of Entrepreneurship and Technology on 13-23 May 2016.

46 Supreme Audit Office, op. cit., pp. 11 and 28.

47 Polish Agency for Enterprise Development, Weszła w życie...
} 
implement in practice. Finally, they may signify a problem entrepreneurs may have with designating the right person who could temporarily manage their enterprise in inheritance when they pass away. But who else is better able to decide whom to entrust running a business activity if not the entrepreneur running this business activity themselves? Given the low rate of utilisation of the option to appoint a succession manager, it seems reasonable to intensify the conducted information campaigns, designing them to both build the awareness of the existence of the solution in question and highlight the easy application thereof.

While it is true that succession management of a natural person's enterprise addresses the need for continuity of a business in the event of its owner's death, the problem of business continuity may occur also when an enterprise's owner does not die but has a serious accident or loses their consciousness as a result of a disease or some other random event. In case any such situation happens, it is essential to secure the operations and existence of a business entity in advance by establishing a proxy. The institution of succession management will not take effect in such an event, and managing a natural person's enterprise may appear impossible.

On account of society ageing, which translates into a growing share of older people among entrepreneurs conducting business activity, the institution of succession management may be increasingly useful. It should be commonly applied. The legislator could consider imposing an obligation on entrepreneurs to appoint a succession manager in case they die. The obligation could be possibly waived only if there is a valid declaration of intent to resign from the application of the said institution. Such a solution could increase the rate of cases where a business activity is continued after the entrepreneur originally running such a business activity dies. 